Check for updates

Cite this: RSC Adv., 2021, 11, 14986

\title{
Fluorinated Iron(II) clathrochelate units in metalorganic based copolymers: improved porosity, iodine uptake, and dye adsorption properties $\dagger$
}

\author{
Suchetha Shetty, ${ }^{\text {ab }}$ Noorullah Baig, ${ }^{\text {ab }}$ Atikur Hassan, (D) ${ }^{c}$ Saleh Al-Mousawi, ${ }^{d}$ \\ Neeladri Das (iD ${ }^{c}$ and Bassam Alameddine (iD) *ab
}

\begin{abstract}
We report the synthesis of metalorganic copolymers made from the palladium catalyzed Sonogashira crosscoupling reaction between various iron(॥) clathrochelate building blocks with diethynyl-triptycene and fluorene derivatives. The target copolymers CCP1-5 were isolated in excellent yield and characterized by various instrumental analysis techniques. Interestingly, investigation of the copolymers' porosity properties discloses BET surface areas up to $337 \mathrm{~m}^{2} \mathrm{~g}^{-1}$ for the target compounds bearing fluorinated iron(॥) clathrochelate units CCP2,5. Moreover, the fluorinated copolymers display an outstanding uptake capacity of iodine with a maximum adsorption of $200 \mathrm{wt} \%$. The target metalorganic copolymers CCP1-5 reveal very good adsorption of organic dyes, namely, methyl blue and methylene blue, from aqueous media.
\end{abstract}

Received 25th March 2021 Accepted 16th April 2021

DOI: 10.1039/d1ra02357h

rsc.li/rsc-advances hands-on synthons which are either commercially available or might require few synthetic steps. In addition, the abovementioned cross-coupling reactions permit a noticeable control over the polymerization reaction, thus, yielding highly structured copolymers. On top that, Suzuki and Sonogashira crosscoupling reactions are powerful synthetic tools for the preparation of porous materials with additional properties, such as, making conjugated polymers, introducing functional groups into the macromolecules' backbones, etc. ${ }^{\mathbf{1 , 2 5}}$ Typically, palladium complexes in combination with copper(I) salts are employed as catalysts in Sonogashira cross-coupling reactions although alternative catalytic systems were also found to be very effective. ${ }^{26-28}$

Iron(II) clathrochelate is a robust metalorganic unit with a considerable internal free volume (IFV) and which can be easily synthesized and functionalized, especially when employed as a building block in cross-coupling reactions. ${ }^{29-31}$ Iron(II) clathrochelate complexes were tested as biosensors, ${ }^{32,33}$ catalysts for hydrogen generation, ${ }^{34,35}$ materials for electronic transport, ${ }^{36}$ organogels, ${ }^{37}$ and to make supramolecular structures of definite shapes and sizes..$^{38-41}$ Recently, several iron(II) clathrochelate based polymers were reported disclosing prominent porous properties. ${ }^{\mathbf{4 2 - 4 4}}$ In this prospect, we report herein the synthesis and characterization of five new iron(II) clathrochelate copolymers CCP1-5 using Sonogashira crosscoupling reaction conditions. Interestingly, the target copolymers exhibit Brunauer-Emmett-Teller (BET) surface area up to $337 \mathrm{~m}^{2} \mathrm{~g}^{-1}$ as well as high iodine uptake and excellent adsorption of organic dyes, namely, methyl blue and methylene blue.

\footnotetext{
${ }^{a}$ Department of Mathematics and Natural Sciences, Gulf University for Science and Technology, Kuwait. E-mail: alameddine.b@gust.edu.kw

${ }^{b}$ Functional Materials Group - CAMB, GUST, Kuwait

${ }^{c}$ Department of Chemistry, Indian Institute of Technology Patna, Patna 801106, Bihar, India

${ }^{d}$ Department of Chemistry, University of Kuwait, Kuwait

$\dagger$ Electronic supplementary information (ESI) available. See DOI: 10.1039/d1ra02357h
} \begin{abstract}
blue.
\end{abstract}




\section{Experimental part}

\subsection{General}

All the reactions were carried out under inert atmosphere using dry argon. All chemical reagents were used without further purification as purchased from Aldrich, Merck, and HiMedia unless otherwise specified. 1,4-Diethynyl-9,10-dihydro-9,10-[1,2] benzenoanthracene 1a, 2,7-diethynyl-9,9-dimethyl-9H-fluorene 1b, and CC1 were prepared according to procedures reported in the literature. ${ }^{\mathbf{4 1 , 4 5 , 4 6}}$ The solvents, namely, DMF, diethyl ether, methanol, hexane, DCM and THF were deoxygenated by bubbling with dry argon gas for 30 minutes. Thin-layer chromatography (TLC) was performed on aluminum sheets coated with silica gel $60 \mathrm{~F} 254$ and revealed using a UV lamp. NMR $\left({ }^{1} \mathrm{H}\right.$ : $600 \mathrm{MHz},{ }^{13} \mathrm{C}$ : $150 \mathrm{MHz}$ ) spectra were recorded on Bruker BioSpin $\mathrm{GmbH} 600$ $\mathrm{MHz}$ spectrometer using $\mathrm{CD}_{2} \mathrm{Cl}_{2}$ as a solvent with the chemical shifts $(\delta)$ given in ppm and referred to tetramethylsilane (TMS). FT-IR spectra were recorded on Agilent Cary 630 FTIR instrument. UV-Vis spectra were recorded on Shimadzu UV1800 spectrophotometer. Brunauer-Emmett-Teller (BET) surface area and porosity measurements were evaluated using a Surface Area and Pore Size Analyzer (Gemini-V, Micromeritics, USA) at the boiling point of liquid nitrogen $\left(-196{ }^{\circ} \mathrm{C}\right)$. Samples were degassed in VacuPrep 061 sample degassing system at a temperature of $105^{\circ} \mathrm{C}$ for overnight, before the experiments. Surface areas (SBET) were calculated using the Brunauer-Emmet-Teller (BET) model of isotherms, and the adsorption of $\mathrm{N}_{2}$ at small relative pressures. Total pore volume $\left(V_{\mathrm{t}}\right)$ was determined from the specific adsorption of $\mathrm{N}_{2}$ at a $p / p^{0}=0.99$. The $t$-plot method was used to estimate micropore volume $\left(V_{\text {mic }}\right)$ and external surface area $\left(S_{\text {ext }}\right)$. Quantachrome Autosorb iQ2 analyzer was used to collect gas adsorption data. In a typical gas uptake setup, samples (120-150 mg) were loaded in a $9 \mathrm{~mm}$ cell and were subjected to degassing at $120{ }^{\circ} \mathrm{C}$ for $5-8 \mathrm{~h}$ by attaching to the degassing unit. The cells with the degassed materials were refilled with helium gas and weighed accurately. Subsequently, cells were reattached to the analysis unit of the instrument for measurements. Various temperatures of the analysis unit sample cell were maintained using KGW isotherm bath that was filled with liquid $\mathrm{N}_{2}(77 \mathrm{~K})$, or using a temperaturecontrolled bath (298 K and $273 \mathrm{~K}$ ). Polymers molecular weights were recorded on Agilent 1260 infinity II gel permeation chromatograph (GPC) against with a refractive index (RI) detector at room temperature and two columns (PL mixed-C) which are calibrated twelve monodisperse polystyrene (PS) standards with THF employed as eluent at a flow rate of $1.0 \mathrm{~mL} \mathrm{~min}^{-1} \mathrm{UV}$-Vis spectra were recorded on Shimadzu UV1800 spectrophotometer. X-ray Photoelectron spectroscopy (XPS) data were recorded with a Thermo ESCALAB $250 \mathrm{Xi}$

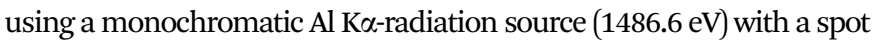
size of $850 \mu \mathrm{m}$. Spectra acquisition and processing were carried out using the software Thermo Advantage Version 4.87. The base pressure in the XPS analysis chamber was in the range $10^{-10}$ to $10^{-9}$ torr. The analyzer was operated with pass energy of $20 \mathrm{eV}$, dwell time of $50 \mathrm{~min}$ and with a step size of $0.1 \mathrm{eV}$.

Electron impact high-resolution mass spectra (EI-HRMS) were recorded on a Thermo (DFS) with a standard PFK (perfluorokerosene) as lock mass. The analyzed data is converted to accurate mass employing X-Calibur accurate mass calculation software.

\subsection{Synthesis}

2.2.1 Synthesis of CC2 (procedure A). A Schlenk tube was charged with nioxime (400 mg, $2.74 \mathrm{mmol}, 3 \mathrm{eq}$.), 4-bromo-2,6difluorophenylboronic acid (500 mg, $2.11 \mathrm{mmol}, 2 \mathrm{eq}$.$) and$ anhydrous $\mathrm{FeCl}_{2}(115 \mathrm{mg}, 0.91 \mathrm{mmol})$ in $\mathrm{MeOH}(20 \mathrm{~mL})$ and the mixture was refluxed for $3 \mathrm{~h}$ under argon. The reaction mixture was allowed to cool to RT, and the resulting precipitate was isolated by filtration, washed with $\mathrm{MeOH}$, diethyl ether, and dried under vacuum to yield a red solid (700 mg, 88\%); ${ }^{1} \mathrm{H}-\mathrm{NMR}(600 \mathrm{MHz}$, $\left.\mathrm{CD}_{2} \mathrm{Cl}_{2}, \mathrm{ppm}\right): \delta 7.05-7.04(\mathrm{~d}, J=6 \mathrm{~Hz}, 4 \mathrm{H}, \mathrm{ArH}), 2.92\left(\mathrm{~s}, 12 \mathrm{H}, \mathrm{CH}_{2}\right)$, $1.83\left(\mathrm{~s}, 12 \mathrm{H}, \mathrm{CH}_{2}\right) ;{ }^{13} \mathrm{C}-\mathrm{NMR}\left(150 \mathrm{MHz}, \mathrm{CD}_{2} \mathrm{Cl}_{2}, \mathrm{ppm}\right): \delta 167.98$, 166.31, 152.96, 122.24,115.69, 26.75, 22.11; HRMS: $m / z$ calculated for $\left(\mathrm{M}^{\cdot+}\right) \mathrm{C}_{30} \mathrm{H}_{28} \mathrm{~B}_{2} \mathrm{Br}_{2} \mathrm{~F}_{4} \mathrm{FeN}_{6} \mathrm{O}_{6} 881.9883$ found 881.9885.

2.2.2 Synthesis of CC3. CC3 was prepared following procedure A with: butyl dioxime (165 mg, $0.82 \mathrm{mmol}, 3$ eq.), 4-bromo2,6-difluorophenylboronic acid (150 mg, $0.633 \mathrm{mmol}, 2$ eq.) and anhydrous $\mathrm{FeCl}_{2}(36 \mathrm{mg}, 0.29 \mathrm{mmol})$ in $\mathrm{MeOH}(10 \mathrm{~mL})$. Red solid (290 mg, 96\%); ${ }^{1} \mathrm{H}-\mathrm{NMR}$ (600 MHz, $\left.\mathrm{CD}_{2} \mathrm{Cl}_{2}, \mathrm{ppm}\right): \delta 7.03-7.02$ (d, $J$ $=6 \mathrm{~Hz}, 4 \mathrm{H}, \mathrm{ArH}), 2.82-2.79\left(\mathrm{t}, J=6 \mathrm{~Hz}, 12 \mathrm{H}, \mathrm{CH}_{2}\right), 1.56-1.53(\mathrm{~m}$, $\left.12 \mathrm{H}, \mathrm{CH}_{2}\right), 1.341 .30\left(\mathrm{~m}, 12 \mathrm{H}, \mathrm{CH}_{2}\right), 0.89-0.86(\mathrm{t}, J=6 \mathrm{~Hz}, 18 \mathrm{H}$, $\left.\mathrm{CH}_{3}\right) ;{ }^{13} \mathrm{C}-\mathrm{NMR}\left(150 \mathrm{MHz}, \mathrm{CD}_{2} \mathrm{Cl}_{2}, \mathrm{ppm}\right): \delta 168.15,166.48,157.94$, 121.92, 115.60, 29.66, 27.69, 23.00 14.06; HRMS: $m / z$ calculated for $\left(\mathrm{M}^{\cdot+}\right) \mathrm{C}_{42} \mathrm{H}_{58} \mathrm{~B}_{2} \mathrm{Br}_{2} \mathrm{~F}_{4} \mathrm{FeN}_{6} \mathrm{O}_{6}$ 1056.2230 found 1056.2236.

2.2.3 Synthesis of copolymer CCP1 (procedure B). A Schlenk tube was charged with a mixture of $\mathrm{DMF}$ and $\mathrm{iPr}_{2} \mathrm{NH}$ $(1: 1,10 \mathrm{~mL}$ ) which was bubbled with argon for $30 \mathrm{~min}$. Before the addition of CC1 (200 mg, $0.25 \mathrm{mmol}, 1 \mathrm{eq}$.) and $\mathbf{1 a}$ ( $75 \mathrm{mg}$, $0.25 \mathrm{mmol}, 1$ eq.). The mixture was purged with argon for $10 \mathrm{~min}$. Before adding CuI (4 mg, $0.02 \mathrm{mmol}, 8 \mathrm{~mol} \%$ ) and $\mathrm{Pd}\left(\mathrm{PPh}_{3}\right)_{4}(23 \mathrm{mg}, 0.02 \mathrm{mmol}, 8 \mathrm{~mol} \%)$ under a positive stream of argon. The reaction was stirred for $48 \mathrm{~h}$ at $110{ }^{\circ} \mathrm{C}$ and the precipitate was isolated by filtration while hot and washed with DMF $(50 \mathrm{~mL})$, water $(50 \mathrm{~mL})$, THF $(50 \mathrm{~mL})$, DCM $(50 \mathrm{~mL})$, acetone $(50 \mathrm{~mL})$, methanol $(50 \mathrm{~mL})$ and diethyl ether $(50 \mathrm{~mL})$ to yield a red solid (211 mg, 90\%); FTIR $\left(\mathrm{cm}^{-1}\right)$ : 2955 (aliphatic-CH stretch.), 2201 (C $\equiv$ C stretch.), 1664 (C=N stretch.), 1550 (NO stretch.), 1431 (aliphatic $-\mathrm{C}-\mathrm{H}$ bend.), and 954 (aromatic $\mathrm{C}=\mathrm{C}$ bend.); UV-vis: (THF, $10^{-8} \mathrm{M}$ ), $\lambda_{\max }[\mathrm{nm}]=329$ and 450 .

2.2.4 Synthesis of copolymer CCP2. CCP2 was prepared following procedure B with: CC2 (200 mg, $0.23 \mathrm{mmol}, 1 \mathrm{eq}$.$) , 1a$ (69 mg, $0.23 \mathrm{mmol}, 1$ eq.), $\mathrm{Pd}\left(\mathrm{PPh}_{3}\right)_{4}(20 \mathrm{mg}, 0.018 \mathrm{mmol}$, $8 \mathrm{~mol} \%$ ) and CuI (3 mg, $0.018 \mathrm{mmol}, 8 \mathrm{~mol} \%)$ in $9 \mathrm{~mL}$ of a $1: 1$ degassed mixture of DMF and $\mathrm{iPr}_{2} \mathrm{NH}$. Red solid (200 mg, 87\%). FTIR $\left(\mathrm{cm}^{-1}\right): 2944$ (aliphatic $-\mathrm{C}-\mathrm{H}$ stretch.), 2201 (C $\equiv \mathrm{C}$ stretch.), 1618 (C=N stretch.), 1545 (N-O stretch.), 1458 (aliphatic $-\mathrm{C}-\mathrm{H}$ bend.), 1395 (C-F stretch.), and 964 (aromatic $\mathrm{C}=\mathrm{C}$ bend.); UV-vis: (THF, $10^{-8} \mathrm{M}$ ), $\lambda_{\max }[\mathrm{nm}]=329$ and 450 .

2.2.5 Synthesis of copolymer CCP3. CCP3 was prepared following procedure B with: CC3 (250 $\mathrm{mg}, 0.24 \mathrm{mmol}, 1 \mathrm{eq}$.$) , 1a$ (72 mg, $0.24 \mathrm{mmol}, 1$ eq.), $\mathrm{Pd}\left(\mathrm{PPh}_{3}\right)_{4}(22 \mathrm{mg}, 0.019 \mathrm{mmol}$, $8 \mathrm{~mol} \%$ ) and $\mathrm{CuI}$ ( $4 \mathrm{mg}, 0.019 \mathrm{mmol}, 8 \mathrm{~mol} \%$ ) in $10 \mathrm{~mL}$ of a $1: 1$ degassed mixture of DMF and $\mathrm{iPr}_{2} \mathrm{NH}$. The solvent was evaporated under reduced pressure and the resulting residue was 


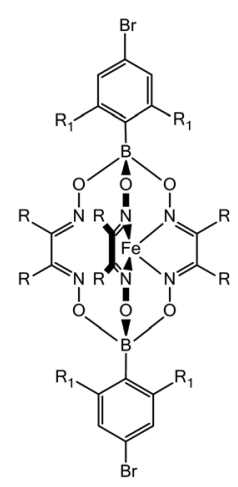

$\mathrm{CC1}: \mathrm{R}=-\left(\mathrm{CH}_{2}\right)_{4^{-}}, \mathrm{R}_{1}=\mathrm{H}$

CC2 : $\mathrm{R}=-\left(\mathrm{CH}_{2}\right)_{4^{-}}, \mathrm{R}_{1}=\mathrm{F}$

CC3 : $\mathrm{R}=-\mathrm{C}_{4} \mathrm{H}_{9}, \quad \mathrm{R}_{1}=\mathrm{F}$

Conditions: $\mathrm{Pd}\left(\mathrm{PPh}_{3}\right)_{4}, \mathrm{CuI}, \mathrm{DMF} / \mathrm{IPr}_{2} \mathrm{NH}(1: 1)$

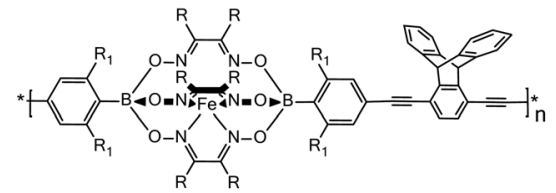

CCP1 : R $=-\left(\mathrm{CH}_{2}\right)_{4^{-}}, \mathrm{R}_{1}=\mathrm{H}$

CCP2: $\mathrm{R}=-\left(\mathrm{CH}_{2}\right)_{4^{-}}, \mathrm{R}_{1}=\mathrm{F}$

CCP3 : R $=-\mathrm{C}_{4} \mathrm{H}_{9}, \quad \mathrm{R}_{1}=\mathrm{F}$

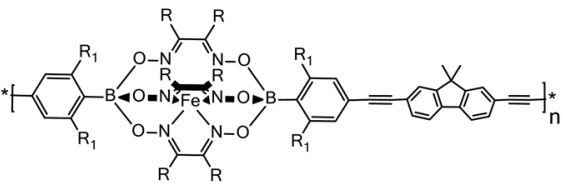

CCP4 : $\mathrm{R}=-\left(\mathrm{CH}_{2}\right)_{4}-, \mathrm{R}_{1}=\mathrm{H}$

CCP5 : $\mathrm{R}=-\left(\mathrm{CH}_{2}\right)_{4^{-}}, \mathrm{R}_{1}=\mathrm{F}$

Scheme 1 Synthesis of copolymers CCP1-5.

extracted with ethyl acetate from an aqueous solution of $10 \%$ LiCl $(100 \mathrm{~mL})$. The organic layer was washed with deionized water $(100 \mathrm{~mL} \times 3)$, concentrated, and the product was precipitated by adding hexane. The precipitate was isolated by filtration under reduced pressure and washed exhaustively with hexane. Red solid (261 mg, 92\%); ${ }^{1} \mathrm{H}-\mathrm{NMR}\left(600 \mathrm{MHz}, \mathrm{CD}_{2} \mathrm{Cl}_{2}\right.$, ppm): $\delta$ 7.60-7.53 (m, 4H, ArH), 7.31-7.09 (m, 10H, ArH), 6.03 (br, $2 \mathrm{H}$, triptycene $\mathrm{CH}), 2.87$ (br, $12 \mathrm{H}$, butyl- $\left.\mathrm{CH}_{2}\right), 1.60(\mathrm{br}, 12 \mathrm{H}$, butyl- $\mathrm{CH}_{2}$ ), 1.38 (br, $12 \mathrm{H}$, butyl- $-\mathrm{CH}_{2}$ ), 0.93 (br, $18 \mathrm{H}$, butyl- $-\mathrm{CH}_{3}$ ); ${ }^{13} \mathrm{C}-\mathrm{NMR}\left(150 \mathrm{MHz}, \mathrm{CD}_{2} \mathrm{Cl}_{2}, \mathrm{ppm}\right): \delta$ 167.96, 166.32, 157.94, 148.21, 145.02, 129.68, 128.68, 126.23, 124.63, 115.58, 115.35, 114.98, 114.76, 52.62, 29.70, 27.69, 23.03, 14.11; FTIR $\left(\mathrm{cm}^{-1}\right)$ : 2958 (aliphatic $-\mathrm{C}-\mathrm{H}$ stretch.), 2210 ( $\mathrm{C} \equiv \mathrm{C}$ stretch.), $1618(\mathrm{C}=\mathrm{N}$ stretch.), 1544 (N-O stretch.), 1458 (aliphatic $-\mathrm{C}-\mathrm{H}$ bend.), 1400 (C-F stretch.), and 716 (aromatic $\mathrm{C}=\mathrm{C}$ bend.); GPC (THF): $M_{\mathrm{w}}(\mathrm{g}$ $\left.\mathrm{mol}^{-1}\right): 14$ 106, $M_{\mathrm{n}}\left(\mathrm{g} \mathrm{mol}^{-1}\right)$ : 7388, $D: 1.9$; UV-vis: (THF, $10^{-8}$ M), $\lambda_{\max }[\mathrm{nm}]=329$ and 450 .

2.2.6 Synthesis of copolymer CCP4. CCP4 was prepared following procedure B with: $\mathbf{C C 1}(300 \mathrm{mg}, 0.37 \mathrm{mmol}, 1$ eq.), 1b (90 mg, $0.37 \mathrm{mmol}, 1$ eq.), $\mathrm{Pd}\left(\mathrm{PPh}_{3}\right)_{4}(34 \mathrm{mg}, 0.03 \mathrm{mmol}$,
$8 \mathrm{~mol} \%$ ) and $\mathrm{CuI}(5 \mathrm{mg}, 0.03 \mathrm{mmol}, 8 \mathrm{~mol} \%)$ in $15 \mathrm{~mL}$ of a $1: 1$ degassed mixture of DMF and $\mathrm{iPr}_{2} \mathrm{NH}$. Red solid (301 mg, 90\%); FTIR $\left(\mathrm{cm}^{-1}\right)$ : 2955 (aliphatic -C-H stretch.), 2201 ( $\mathrm{C} \equiv \mathrm{C}$ stretch.), 1602 ( $\mathrm{C}=\mathrm{N}$ stretch.), 1492 ( $\mathrm{N}-\mathrm{O}$ stretch.), 1434 (aliphatic $-\mathrm{C}-\mathrm{H}$ bend.), and 960 (aromatic $\mathrm{C}=\mathrm{C}$ bend.); UV-vis: (THF, $10^{-8} \mathrm{M}$ ), $\lambda_{\max }[\mathrm{nm}]=354,371,400$ and 450.

2.2.7 Synthesis of copolymer CCP5. CCP5 was prepared following procedure B with: CC2 (180 mg, $0.21 \mathrm{mmol}, 1$ eq.), $\mathbf{1 b}$ (50 mg, $0.21 \mathrm{mmol}, 1$ eq.), $\mathrm{Pd}\left(\mathrm{PPh}_{3}\right)_{4}(19 \mathrm{mg}, 0.017 \mathrm{mmol}, 8 \mathrm{~mol} \%)$

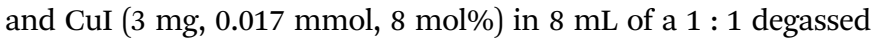
mixture of DMF and $\mathrm{iPr}_{2} \mathrm{NH}$. Red solid (188 $\mathrm{mg}$, 95\%); FTIR $\left(\mathrm{cm}^{-1}\right): 2942$ (aliphatic $-\mathrm{C}-\mathrm{H}$ stretch.), 2207 (C $\equiv \mathrm{C}$ stretch.), 1618 $(\mathrm{C}=\mathrm{N}$ stretch.), 1542 ( $\mathrm{N}-\mathrm{O}$ stretch.), 1436 (aliphatic $-\mathrm{C}-\mathrm{H}$ bend.), 1396 (C-F stretch.), and 959 (aromatic $\mathrm{C}=\mathrm{C}$ bend.); UV-vis: (THF, $\left.10^{-8} \mathrm{M}\right), \lambda_{\max }[\mathrm{nm}]=354,371,400$ and 450.

\section{Results and discussion}

Scheme 1 depicts the synthetic strategy which was devised to prepare the target clathrochelate copolymers CCP1-5 via

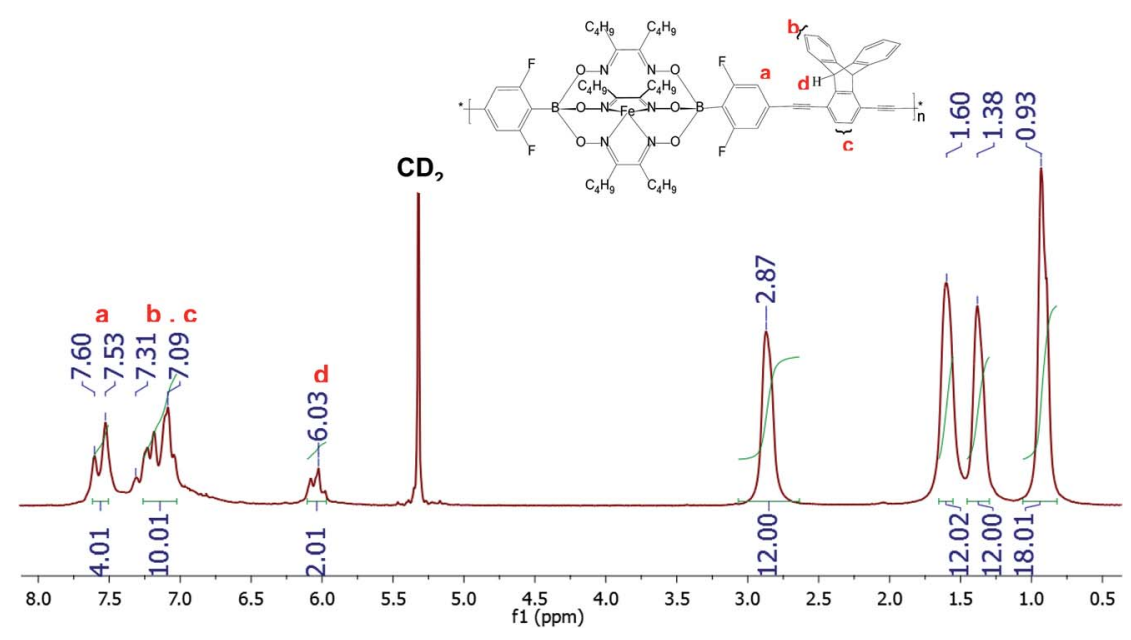

Fig. $1{ }^{1} \mathrm{H}$-NMR spectrum of $\mathrm{CCP} 3$ recorded in $\mathrm{CD}_{2} \mathrm{Cl}_{2}$. 


(1)

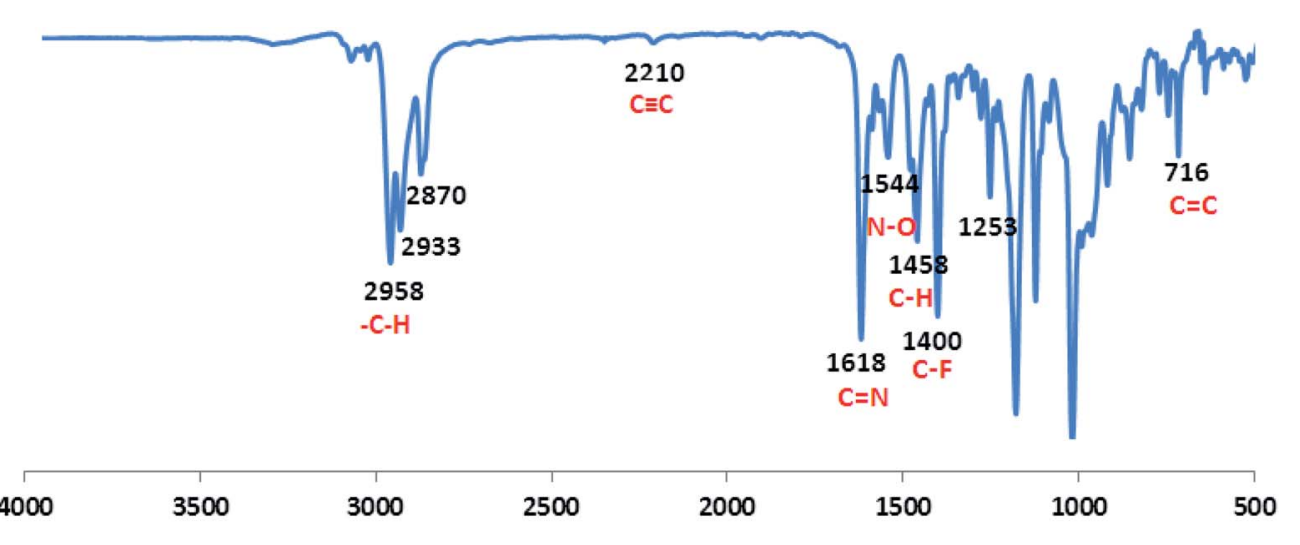

Wavenumber $\left(\mathrm{cm}^{-1}\right)$

Fig. 2 FTIR spectrum of CCP3.

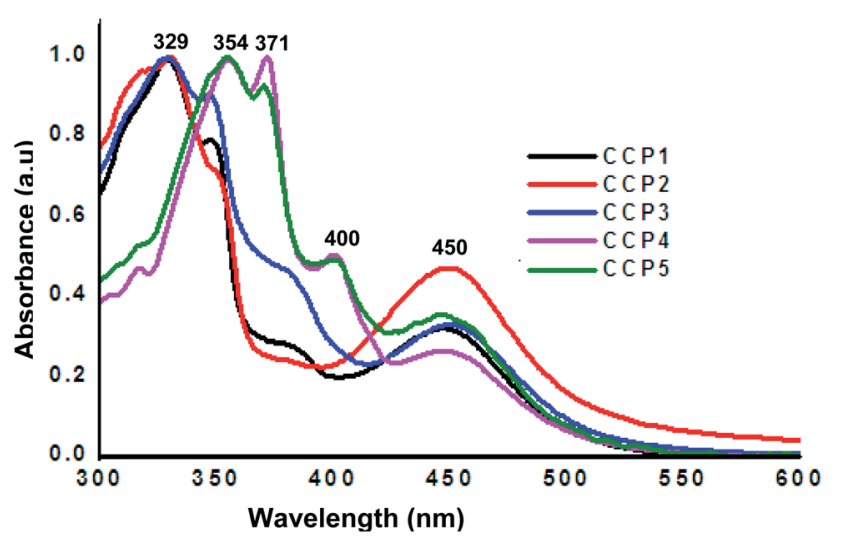

Fig. 3 Normalized UV-Vis absorption ( $C_{M}=10^{-8} \mathrm{M}$ in THF) spectra of CCP1-5.

a typical Sonogashira cross-coupling reaction condition using the dibrominated iron(II) clathrochelate synthons CC1-3 with each of 1,4-diethynyl triptycene 1a and 2,7-diethynyl-9,9dimethyl fluorene 1b. The desired copolymers CCP1-5 were isolated after 2 days of reaction at $110{ }^{\circ} \mathrm{C}$ by simple filtration while hot followed by exhaustive sequential washings of the precipitates with hot solvents, thus, affording the desired target materials in excellent yields (87-95\%). The copolymers whose clathrochelate units bear cyclohexyl side groups (i.e. CCP1,2,4,5) were found to be highly insoluble in common organic solvents. Consequently, the hitherto mentioned four copolymers were characterized using FTIR and XPS spectroscopy (Fig. S8-S15 in the $\mathrm{ESI} \dagger$ file). Nevertheless, copolymer CCP3, which contains clathrochelate units with the more flexible butyl side groups, was found to be soluble in most common organic solvents (e.g. DCM, THF, chloroform, acetone, and DMF), therefore, allowing for its thorough structural analysis by ${ }^{1} \mathrm{H}-$ and ${ }^{13} \mathrm{C}$ - NMR, FTIR, and XPS spectroscopy (Fig. 1, 2, 4 and S5 in the ESI $\dagger$ file).

Fig. 1 below portrays the ${ }^{1} \mathrm{H}-\mathrm{NMR}$ spectrum of CCP3 in $\mathrm{CD}_{2} \mathrm{Cl}_{2}$ where the chemical shifts ranging from $7.60 \mathrm{ppm}$ to $7.53 \mathrm{ppm}$ are attributed to the four aromatic protons of the difluorobenzene boronate groups of the iron(II) clathrochelate unit whereas the four peaks observed at $2.87 \mathrm{ppm}, 1.6 \mathrm{ppm}$, $1.38 \mathrm{ppm}$, and $0.93 \mathrm{ppm}$ are assigned to the butyl side chains. Furthermore, the characteristic chemical shift of the $\mathrm{sp}^{3}$ protons in the triptycene unit is detected at $6.03 \mathrm{ppm}$ whereas the aromatic protons of this latter are identified in the range of 7.31-7.09 ppm. In addition, ${ }^{13} \mathrm{C}-\mathrm{NMR}$ spectrum of CCP3 displays all the characteristic chemical shifts, which further confirms its successful formation in high purity (Fig. S5 in the $\mathrm{ESI} \dagger$ file).

The FT-IR absorption spectrum shown in Fig. 2 divulges all the desired peaks of target copolymer CCP3 which clearly confirms its formation. Hence, the peaks observed at $1618 \mathrm{~cm}^{-1}$ and $1400 \mathrm{~cm}^{-1}$ are attributed to the characteristic stretching vibrations of $\mathrm{C}=\mathrm{N}$ and $\mathrm{C}-\mathrm{F}$, respectively. Similarly, the peaks detected at $2958 \mathrm{~cm}^{-1}$ and $1544 \mathrm{~cm}^{-1}$ are assigned to the stretching vibrations of the aliphatic $\mathrm{C}-\mathrm{H}$ and $\mathrm{N}-\mathrm{O}$ groups, respectively. Moreover, the absorption peaks identified at $1458 \mathrm{~cm}^{-1}$ and $716 \mathrm{~cm}^{-1}$ correspond to the bending vibrations of the aliphatic $\mathrm{C}-\mathrm{H}$ and aromatic $\mathrm{C}=\mathrm{C}$, respectively. It is noteworthy that the $\mathrm{C} \equiv \mathrm{C}$ stretching vibrations is also spotted at $2210 \mathrm{~cm}^{-1}$. Similarly, all the other target copolymers disclose the characteristic peaks, thus, confirming their successful synthesis (Fig. S8-S11 in the ESI $\uparrow$ file).

The photophysical properties of CCP1-5 were investigated by means of UV-Vis absorption spectroscopy using THF as a solvent (Fig. 3). Iron(II) clathrochelate copolymers with triptycene units CCP1-3 display analogous absorption bands with two peaks maxima at $\sim 329 \mathrm{~nm}$ and $450 \mathrm{~nm}$, where the former can be attributed to the absorption of triptycene ${ }^{47}$ while the latter corresponds to the clathrochelate moiety. ${ }^{47}$ On the other hand, clathrochelate copolymers with fluorene units CCP4,5 display three main absorption bands maxima, two of which are attributed to fluorene at $\sim 354 \mathrm{~nm}$ and $371 \mathrm{~nm},{ }^{48}$ whereas the one detected at $450 \mathrm{~nm}$ corresponds to the clathrochelate unit.

X-ray photoelectron spectroscopy (XPS) was utilized to analyze the elemental composition of copolymers CCP1-5. XPS survey-scan spectrum of CCP3, shown in Fig. 4 below, confirms the presence of all the constituting elements i.e. carbon, oxygen, nitrogen, iron, fluorine, and boron. ${ }^{49} \mathrm{C} 1 \mathrm{~s}$ peak of CCP3 can be 


$\begin{array}{lr}\text { Name } & \text { Peak BE } \\ \text { C1s } & 284.62 \\ \text { C1s A } & 285.23 \\ \text { C1s B } & 287.09 \\ \text { O1s } & 532.35 \\ \text { O1s A } & 532.21 \\ \text { N1s } & 400.63 \\ \text { N1s A } & 401.52 \\ \text { Fe2p } & 709.33 \\ \text { Fe2p } & 722.15 \\ \text { F1s } & 686.65 \\ \text { B1s } & 190.65\end{array}$

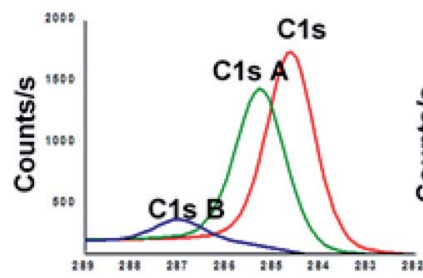

Binding energy (eV)
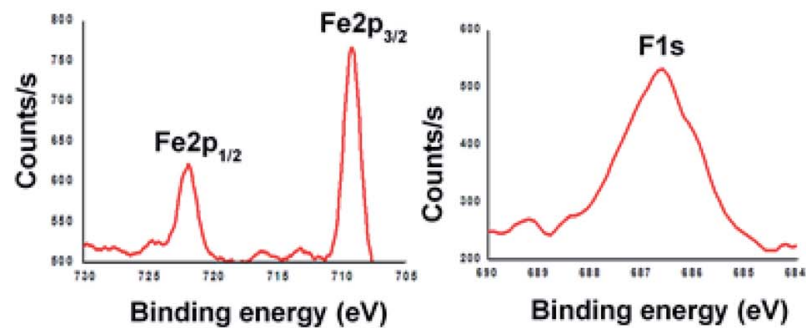

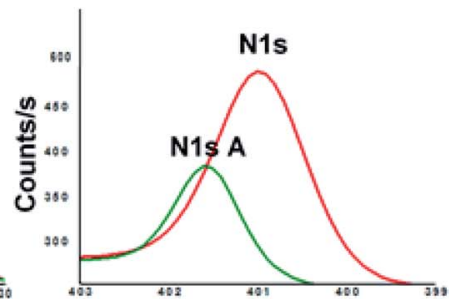

Binding energy (eV)

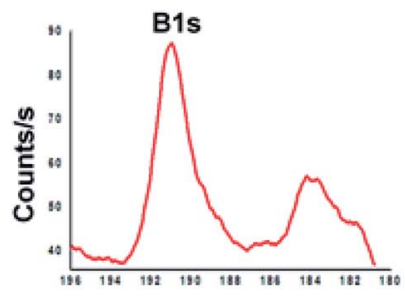

Binding energy (eV)

Fig. 4 High-resolution XPS spectra of C1s, O1s, N1s, Fe2p, F1s and B1s of CCP3.

fitted into two main binding energy values at $\sim 284.62 \mathrm{eV}$ and $285.23 \mathrm{eV}$ where the former is assigned to the aromatic carbon groups $(\mathrm{C}=\mathrm{C})$ whereas the latter corresponds to that of imine carbons $(\mathrm{C}=\mathrm{N})$. The binding energy for oxygen detected at $\sim 532.3 \mathrm{eV}$ relates to a hydrocarbon bonded to boron and nitrogen. On the other hand, N1s spectrum exhibits two peaks at $400.63 \mathrm{eV}$ and $401.52 \mathrm{eV}$, which correspond to carbonnitrogen $(\mathrm{C}-\mathrm{N})$ and nitrogen-oxygen $(\mathrm{N}-\mathrm{O})$, respectively. F1s core-level spectrum was detected at $685.65 \mathrm{eV}$, thus, indicating the presence of $\mathrm{C}-\mathrm{F} .{ }^{50} \mathrm{~B} 1 \mathrm{~s}$ core-level spectrum was detected at $190.65 \mathrm{eV}$, which clearly divulges the presence of boron oxide (B-O) usually observed above $190 \mathrm{eV}{ }^{51}$ Fig. 4 also reveals the XPS peak for Fe2p with binding energy values of $709.33 \mathrm{eV}$ and $722.15 \mathrm{eV}$, which are attributed to Fe(II)-N compounds. ${ }^{52}$ It is noteworthy that the other target copolymers CCP2-5 portray similar XPS binding energy values, which undoubtedly confirm their structures (Fig. S12-S15 in the ESI $\dagger$ file).

As it could be noticed from Fig. 5, the relatively good solubility of clathrochelate copolymer CCP3 in common organic

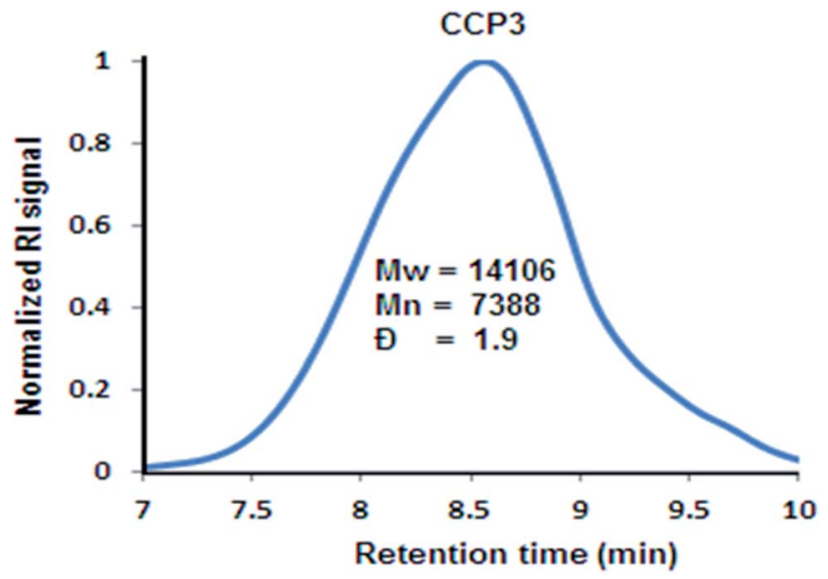

Fig. 5 Normalized GPC chromatograph of CCP3 solvents has allowed for the determination of its molar weight by gel permeation chromatography (GPC), revealing a weight average molar mass $M_{\mathrm{w}}$ of $\sim 14 \mathrm{kDa}$ and number average molar mass Mn of $\sim 7 \mathrm{kDa}$, thus, showing a polydispersity index (PDI $\left.=M_{\mathrm{w}} / M_{\mathrm{n}}\right)$ of $\sim 1.9$. Nevertheless, the scarce solubility of the triptycene-containing copolymers CCP1,2 and those bearing dimethyl fluorene units CCP4,5 in common organic solvents prevented recording their GPC chromatograms.

\section{Surface area and porosity analysis}

The surface areas and porous properties of copolymers CCP1-5 were investigated by carrying out $\mathrm{N}_{2}$ adsorption experiments at $77 \mathrm{~K}$ and low relative pressure (Fig. 6). Table 1 below summarizes the Brunauer-Emmett-Teller (BET) surface areas and pore volumes derived from the nitrogen sorption isotherms. Unsurprisingly, CCP3 divulges the lowest BET surface area $\left(\sim 45 \mathrm{~m}^{2}\right.$ $\mathrm{g}^{-1}$ ) which can be explained by the presence of the flexible butyl side chains which block the intrinsic pores. ${ }^{44}$ The clathrochelate copolymers bearing triptycene CCP1 and dimethyl fluorene CCP4 units portray surface areas of $\sim 79 \mathrm{~m}^{2} \mathrm{~g}^{-1}$ and $111 \mathrm{~m}^{2} \mathrm{~g}^{-1}$ CCP1,3, respectively. Interestingly, the replacement of the two hydrogen atoms located at the ortho positions with respect to boron with the bulkier and more electronegative fluorine atoms in the iron(II) clathrochelate moiety of both copolymers i.e. the one with dimethyl fluorene units $\mathbf{C C P 5}$ and that with triptycene derivatives CCP2 resulted in a noticeable increase of the surface areas of $279 \mathrm{~m}^{2} \mathrm{~g}^{-1}$, for the former and $337 \mathrm{~m}^{2} \mathrm{~g}^{-1}$, for the latter. All five target copolymers were found to have pore volumes ranging between $0.039 \mathrm{~cm}^{3} \mathrm{~g}^{-1}$ and $0.222 \mathrm{~cm}^{3} \mathrm{~g}^{-1}$ (Table 1).

\section{5. lodine uptake study}

Copolymers CCP1-5 were explored as potential iodine adsorbents using a standard gravimetric analysis protocol reported in 

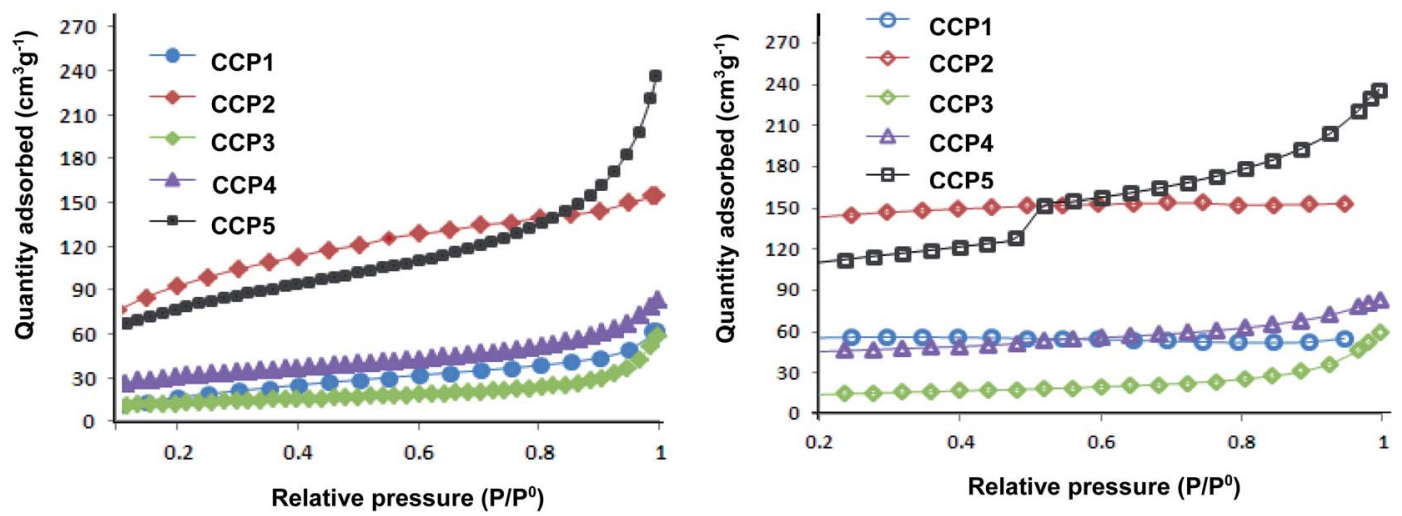

Fig. 6 Nitrogen adsorption (left) and desorption isotherms (right) of CCP1-5 measured at $77 \mathrm{~K}$.

Table 1 Summary of the microporosity properties of polymers CCP1-

\begin{tabular}{llll}
\hline Entry & Polymer & $\begin{array}{l}\text { BET surface area } \\
\left(\mathrm{m}^{2} \mathrm{~g}^{-1}\right)\end{array}$ & $\begin{array}{l}\text { Pore volume } \\
\left(\mathrm{cm}^{3} \mathrm{~g}^{-1}\right)\end{array}$ \\
\hline 1 & CCP1 & 79 & 0.086 \\
2 & CCP2 & 337 & 0.214 \\
3 & CCP3 & 45 & 0.039 \\
4 & CCP4 & 111 & 0.085 \\
5 & CCP5 & 279 & 0.222
\end{tabular}

the literature..$^{53,54}$ The iodine uptake tests were conducted by placing a $10 \mathrm{mg}$ sample for each of copolymers CCP1-5 in an open glass vial, which was in turn put inside a sealed glass vessel that contained excess solid iodine at $80{ }^{\circ} \mathrm{C}$ under atmospheric pressure and the gravimetric analysis was subsequently recorded at different time intervals (Fig. 7). Evidently, the fluorinated iron (II) clathrochelate copolymers which revealed superior BET surface areas, i.e. CCP2 and CCP5, display the highest iodine uptake reaching a maximum of $200 \mathrm{wt} \%$. It is noteworthy that iodine adsorption of $\mathbf{C C P 2}$ reached $\sim 160 \mathrm{wt} \%$ after 6 hours of exposure while that of CCP5 attained $150 \mathrm{wt} \%$ for the same period time. On the other hand, the maximum uptake capacities of copolymers CCP1 and CCP4 were found to
Table 2 Summary of iodine adsorption and desorption of copolymers CCP1-5

\begin{tabular}{llll}
\hline Entry & Time (h) & $\begin{array}{l}\text { Wt\% } \mathrm{I}_{2} \text { adsorption } \\
\text { after } 24 \mathrm{~h}\end{array}$ & $\begin{array}{l}\text { Wt\% } \mathrm{I}_{2} \text { desorption } \\
\text { after } 4 \mathrm{~h}\end{array}$ \\
\hline 1 & CCP1 & 160 & 160 \\
2 & CCP2 & 200 & 199 \\
3 & CCP3 & 120 & 119 \\
4 & CCP4 & 140 & 140 \\
5 & CCP5 & 200 & 200 \\
\hline
\end{tabular}

reach $160 \mathrm{wt} \%$ and $140 \mathrm{wt} \%$, respectively, after 24 hours of exposure to $\mathrm{I}_{2}$ (Table 2). The $200 \mathrm{wt} \%$ uptake for CCP2 and CCP5 to iodine is promising because of the several advantages these copolymers present, namely, their versatile synthesis from commercially available synthons and the ease of their isolation, especially when compared to the polymer networks reported in the literature which require intricate synthetic and/or purification steps and whose iodine adsorption values are either lower or approximately equal to the ones presented herein. ${ }^{53-65}$

Iodine-containing copolymers CCP1-5 ( $\left.\mathrm{I}_{2} @ \mathbf{C C P 1}-5\right)$ underwent desorption by simple heating in air at $120{ }^{\circ} \mathrm{C}$. The complete $\mathrm{wt} \%$ of iodine released from $\mathrm{I}_{2} @ \mathbf{C C P 1}-5$ samples was recorded at different time intervals (Fig. 7 and Table 2). In addition, reusability tests of the copolymers were carried out
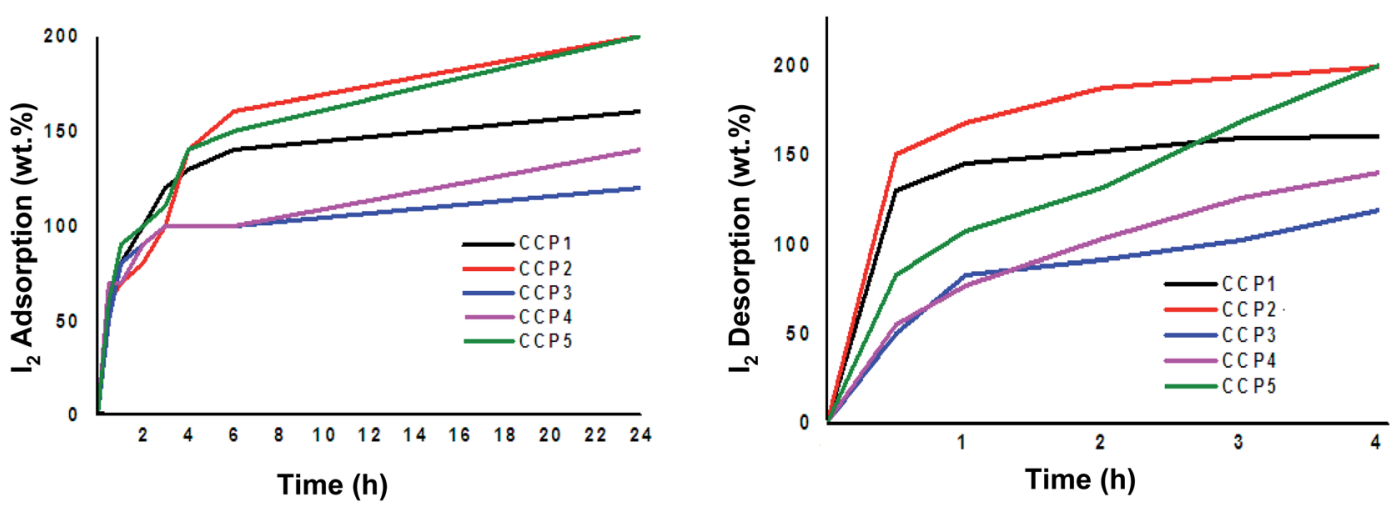

Fig. 7 Wt\% iodine adsorption (left) and desorption (right) graphs of CCP1-5. 


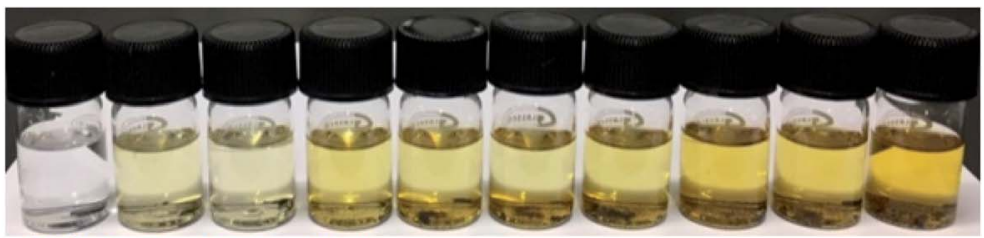

$0 \mathrm{~min} 5 \mathrm{minn} 10 \mathrm{~min} 15 \mathrm{~min} 20 \mathrm{~min} 25 \mathrm{~min} 30 \mathrm{~min} 35 \mathrm{~min} 40 \mathrm{~min} 45 \mathrm{~min}$

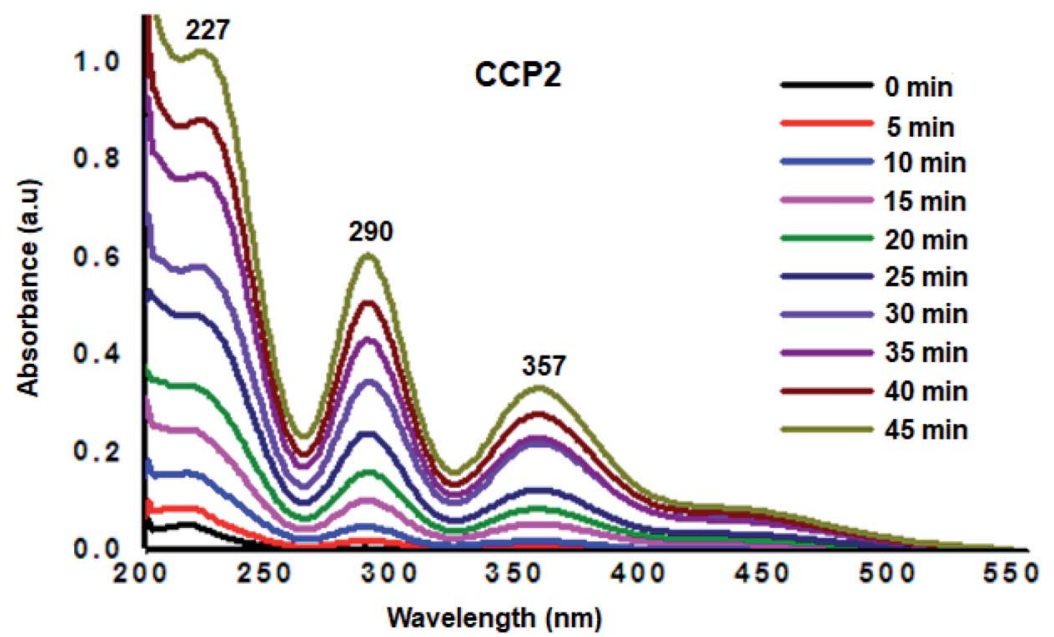

Fig. 8 UV-Vis absorption spectra upon immersion of $\mathrm{I}_{2} \mathrm{QCCP} 2$ in ethanol. Inset: photos of the solutions showing the color change upon immersion in ethanol.

using CCP2 as a model sample because it disclosed the maximum uptake capacity for iodine. Hence, a sample of CCP2 fully loaded with iodine i.e. $\mathrm{I}_{2} @ \mathbf{C C P} 2$ was heated at $120^{\circ} \mathrm{C}$ for 24 hours, to ensure the complete release of the adsorbate. The reactivated sample CCP2 was subsequently exposed to iodine vapors and its uptake values were recorded gravimetrically using the procedure described above, which revealed similar results to a freshly prepared copolymer after three iodine adsorption-desorption cycles.

Additional desorption tests were investigated by immersing fully loaded samples of $\mathrm{I}_{2}$ @CCP1-5 in ethanol, where the latter is an excellent solvent for iodine. The release of iodine from $I_{2} @$ CCP1-5 samples suspended in ethanol was analyzed by recording the UV-visible absorbance spectra of ethanol at
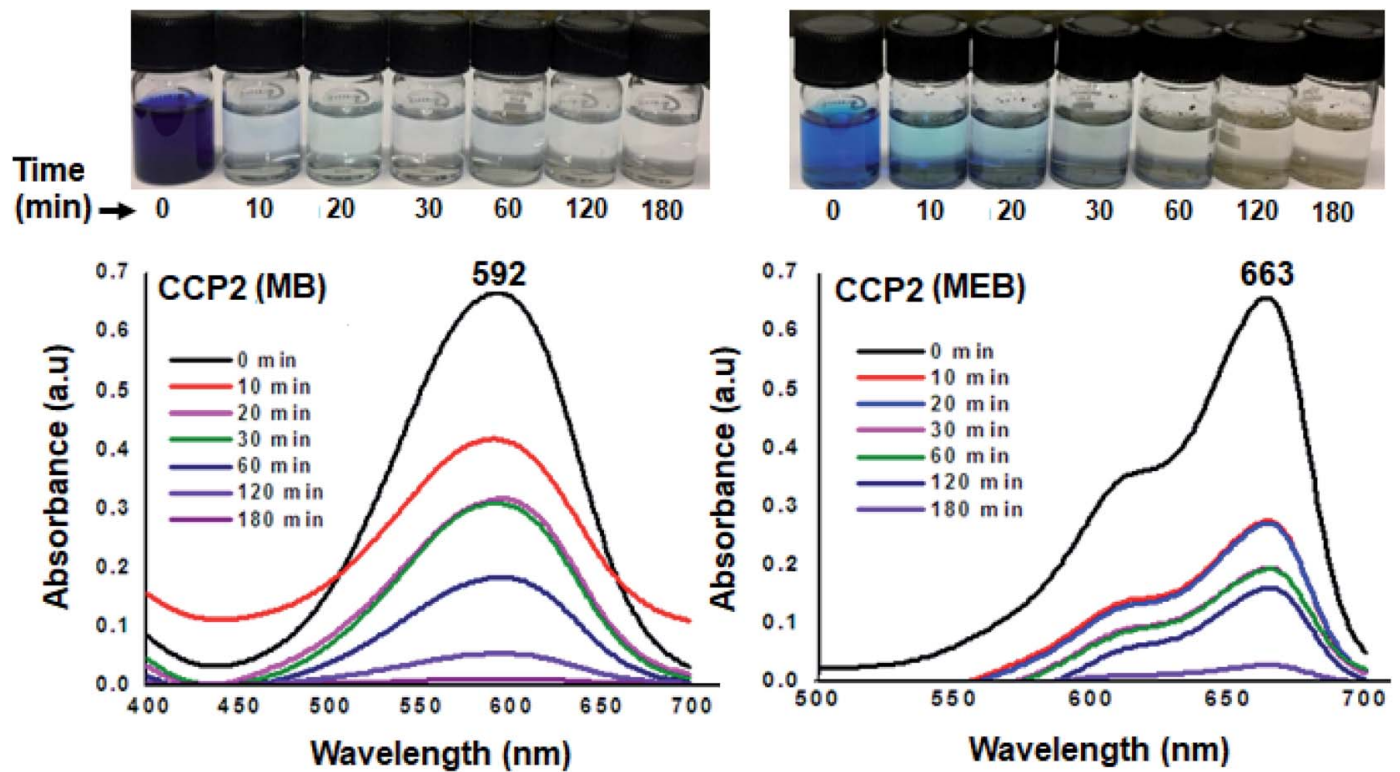

Fig. 9 UV-Vis absorption spectra of aqueous solution MB (left) and MEB (right) in the presence of CCP2 at various time intervals (inset: photographs showing the color change upon dye adsorption). 
different time intervals (Fig. 8 and S16-S19 in the ESI $\dagger$ file). A conspicuous increase was observed in the absorbance intensity maxima which correspond to iodine, namely, at $\sim 227 \mathrm{~nm}$ (due to $\mathrm{I}_{2}$ ), $\sim 290 \mathrm{~nm}$ and $\sim 357 \mathrm{~nm}$ (due to polyiodide ions), which confirms the release of the adsorbate from CCP1-5 samples under ambient conditions. It is noteworthy that the amount of iodine released from CCP1-5 reached equilibrium after 45 minutes with a clear change in the color intensity of the solution from colorless to yellow (Fig. 8). These experimental observations strongly suggest that copolymers CCP1-5 can be employed as efficient iodine sorbents and can be easily regenerated either by simple heating or soaking in ethanol, therefore, rendering the recycling process very practical.

\section{Dye adsorption}

The efficiency of the clathrochelate-based copolymers CCP1-5 to adsorb dyes from aqueous solution was carried out using methyl blue (MB, anionic dye) and methylene blue (MEB, cationic dye). The former is an important reagent for various biological and industrial applications whereas the latter is considered to be a primary source of pollution in water resources. ${ }^{\mathbf{8} 66-69}$ The capacity of CCP1-5 to adsorb MB and MEB was investigated by stirring at ambient temperature a $4 \mathrm{mg}$ sample of a target copolymer in a $5 \mathrm{~mL}$ of a $5 \mathrm{mg} \mathrm{L}^{-1}$ aqueous solution of either MB or MEB dyes. The adsorption tests were performed by recording the UV-visible absorbance spectra at different time intervals (Fig. 9 and $\mathrm{S} 20-\mathrm{S} 27$ in the ESI $\dagger$ file). Interestingly, all the clathrochelate-based copolymers CCP1-5 demonstrated an excellent adsorption capacity towards MB where more than $95 \%$ of the latter was removed within $2 \mathrm{~h}$ of reaction and a $100 \%$ adsorption was detected after $3 \mathrm{~h}$ of reaction. On the other hand, target copolymers CCP1-5 revealed a less efficient adsorption capacity towards MEB except for CCP2 which disclosed the adsorption of $\sim 70 \%$ of the dye in 10 minutes and $\sim 100 \%$ after $3 \mathrm{~h}$ (Fig. 9). Target copolymers CCP1,3-5 adsorbed only $\sim 70-80 \%$ of MEB even after long reaction times (Fig. S20-S27 in the ESI $\dagger$ file).

\section{Conclusion}

Five metalorganic copolymers CCP1-5 were prepared in very good yields via a one-step Sonogashira cross-coupling reaction between various dibrominated iron(II) clathrochelate units with 1,4-diethynyl triptycene and 2,7-diethynyl-9,9-dimethyl fluorene synthons. Gel permeation chromatography of the soluble target copolymer CCP3 disclosed weight average molar mass $M_{\mathrm{w}}$ of $\sim 14 \mathrm{kDa}$ and number average molar mass, Mn of $\sim 7 \mathrm{kDa}$. Porosity investigation divulged BET surface areas ranging from 45 to $337 \mathrm{~m}^{2} \mathrm{~g}^{-1}$ with greater porosity values for the fluorinated copolymers CCP5 bearing fluorene derivatives and CCP2 containing triptycene units, which disclosed surface areas of 279 $\mathrm{m}^{2} \mathrm{~g}^{-1}$ for the former copolymer and $337 \mathrm{~m}^{2} \mathrm{~g}^{-1}$ for the latter. Likewise, iodine uptake studies depicted adsorption capacities up to $200 \mathrm{wt} \%$ for the fluorinated copolymers CCP2,5. Furthermore, CCP1-5 demonstrate efficient adsorption of both methyl blue and methylene blue from aqueous solution with a higher preference towards the former. It is worth mentioning that the metalorganic copolymers CCP1-5 present several advantages, among others, their ease of synthesis and isolation, superior stability, in addition to the possibility for their utilization in the treatment of emission of toxic iodine vapors and organic dyes.

\section{Conflicts of interest}

There are no conflicts to declare.

\section{Acknowledgements}

The project was partially supported by Kuwait Foundation for the Advancement of Sciences (KFAS) under project codes P31434SC-01 and PN18-14SC-03. N. D. thanks the Indian Institute of Technology Patna (IIT Patna) for providing instrumental facilities required for the research. A. H. thanks IIT Patna for providing a research fellowship. We would like to thank the general facilities projects GS01/03, GS01/05, GS03/01, and GS03/ 08 at Kuwait University.

\section{References}

1 J.-S. M. Lee and A. I. Cooper, Chem. Rev., 2020, 120, 21712214.

2 R. S. Sprick, Y. Bai, A. A. Y. Guilbert, M. Zbiri, C. M. Aitchison, L. Wilbraham, Y. Yan, D. J. Woods, M. A. Zwijnenburg and A. I. Cooper, Chem. Mater., 2019, 31, 305-313.

3 X. Yu, Z. Yang, B. Qiu, S. Guo, P. Yang, B. Yu, H. Zhang, Y. Zhao, X. Yang, B. Han and Z. Liu, Angew. Chem., Int. Ed., 2019, 58, 632-636.

4 J. Guo, L. Yu and H. Yue, React. Funct. Polym., 2019, 135, 5864.

5 Z.-X. Low, P. M. Budd, N. B. McKeown and D. A. Patterson, Chem. Rev., 2018, 118, 5871-5911.

6 Y. Zhao, W. Ma, Y. Xu, C. Zhang, Q. Wang, T. Yang, X. Gao, F. Wang, C. Yan and J.-X. Jiang, Macromolecules, 2018, 51, 9502-9508.

7 S. Das, P. Heasman, T. Ben and S. Qiu, Chem. Rev., 2017, 117, 1515-1563.

8 M. Kalaj, K. C. Bentz, S. Ayala, J. M. Palomba, K. S. Barcus, Y. Katayama and S. M. Cohen, Chem. Rev., 2020, 120, 82678302.

9 J. Yu, L.-H. Xie, J.-R. Li, Y. Ma, J. M. Seminario and P. B. Balbuena, Chem. Rev., 2017, 117, 9674-9754.

10 K. Geng, T. He, R. Liu, K. T. Tan, Z. Li, S. Tao, Y. Gong, Q. Jiang and D. Jiang, Chem. Rev., 2020, 120, 8814-8933.

11 R. K. Sharma, P. Yadav, M. Yadav, R. Gupta, P. Rana, A. Srivastava, R. Zbořil, R. S. Varma, M. Antonietti and M. B. Gawande, Mater. Horiz., 2020, 7, 411-454.

12 G. Kupgan, L. J. Abbott, K. E. Hart and C. M. Colina, Chem. Rev., 2018, 118, 5488-5538.

13 A. B. Foster, M. Tamaddondar, J. M. Luque-Alled, W. J. Harrison, Z. Li, P. Gorgojo and P. M. Budd, Macromolecules, 2020, 5, 569-583. 
14 B. Comesaña-Gándara, J. Chen, C. G. Bezzu, M. Carta, I. Rose, M.-C. Ferrari, E. Esposito, A. Fuoco, J. C. Jansen and N. B. McKeown, Energy Environ. Sci., 2019, 12, 27332740 .

15 S. Shetty, N. Baig, A. Hassan, S. Al-Mousawi, N. Das and B. Alameddine, Microporous Mesoporous Mater., 2020, 303, 110256.

16 H. Hong, Z. Guo, D. Yan and H. Zhan, Microporous Mesoporous Mater., 2020, 294, 109870.

17 Z. Zhu, J. Zhu, J. Li and X. Ma, Macromolecules, 2020, 53, 1573-1584.

18 M. A. Abdulhamid, H. W. H. Lai, Y. Wang, Z. Jin, Y. C. Teo, X. Ma, I. Pinnau and Y. Xia, Chem. Mater., 2019, 31, 17671774.

19 S. Neyertz and D. Brown, Macromolecules, 2018, 51, 70777092.

20 I. Rose, C. G. Bezzu, M. Carta, B. Comesana-Gandara, E. Lasseuguette, M. C. Ferrari, P. Bernardo, G. Clarizia, A. Fuoco, J. C. Jansen, K. E. Hart, T. P. Liyana-Arachchi, C. M. Colina and N. B. McKeown, Nat. Mater., 2017, 16, 932-937.

21 M. Galizia, W. S. Chi, Z. P. Smith, T. C. Merkel, R. W. Baker and B. D. Freeman, Macromolecules, 2017, 50, 7809-7843.

22 M. D. Waseem Hussain, S. Bandyopadhyay and A. Patra, Chem. Commun., 2017, 53, 10576-10579.

23 N. Miyaura, T. Yanagai and A. Suzuki, Synth. Commun., 1981, 11, 513-519.

24 S. Takahashi, Y. Kuroyama, K. Sonogashira and N. Hagihara, Synthesis, 1980, 627-629.

25 N. Baig, S. Shetty, S. Al-Mousawi, F. Al-Sagheer and B. Alameddine, React. Funct. Polym., 2019, 139, 153-161.

26 M. Schilz and H. Plenio, J. Org. Chem., 2012, 77, 2798-2807.

27 T. Lauterbach, M. Livendahl, A. Rosellón, P. Espinet and A. M. Echavarren, Org. Lett., 2010, 12, 3006-3009.

28 H. Plenio, Angew. Chem., Int. Ed., 2008, 47, 6954-6956.

29 I. N. Denisenko, O. A. Varzatskii, R. A. Selin, A. S. Belov, E. G. Lebed, A. V. Vologzhanina, Y. V. Zubavichus and Y. Z. Voloshin, RSC Adv., 2018, 8, 13578-13587.

30 O. A. Varzatskii, S. V. Shul'ga, A. S. Belov, V. V. Novikov, A. V. Dolganov, A. V. Vologzhanin and Y. Z. Voloshin, Dalton Trans., 2014, 43, 17934-17948.

31 M. D. Wise, A. Ruggi, M. Pascu, R. Scopelliti and K. Severin, Chem. Sci., 2013, 4, 1658-1662.

32 R. O. Selin, I. Klemt, V. Y. Chernii, M. Y. Losytskyy, S. Chernii, A. Mular, E. Gumienna-Kontecka, V. B. Kovalska, Y. Z. Voloshin, A. V. Vologzhanina, P. V. Dorovatovskii and A. Mokhir, RSC Adv., 2021, 11, 8163-8177.

33 V. Kovalska, S. Vakarov, M. Losytskyy, M. Kuperman, N. Chornenka, Y. Toporivska, E. Gumienna-Kontecka, Y. Voloshin, O. Varzatskii and A. Mokhir, RSC Adv., 2019, 9, 24218-24230.

34 G. E. Zelinskii, A. A. Pavlov, A. S. Belov, I. G. Belaya, A. V. Vologzhanina, Y. V. Nelyubina, N. N. Efimov, Y. V. Zubavichus, Y. N. Bubnov, V. V. Novikov and Y. Z. Voloshin, ACS Omega, 2017, 2, 6852-6862.
35 S. El Ghachtouli, M. Fournier, S. Cherdo, R. Guillot, M.-F. Charlot, E. Anxolabéhère-Mallart, M. Robert and A. Aukauloo, J. Phys. Chem. C, 2013, 117, 17073-17077.

36 S. M. Jansze and K. Severin, Acc. Chem. Res., 2018, 51, 21392147.

37 B. Alameddine, S. Shetty, R. S. Anju, F. Al-Sagheer and S. AlMousawi, Eur. Polym. J., 2017, 95, 566-574.

38 O. M. Planes, P. A. Schouwink, J. L. Bila, F. Fadaei-Tirani, R. Scopelliti and K. Severin, Cryst. Growth Des., 2020, 20, 1394-1399.

39 G. E. Zelinskii, S. V. Dudkin, A. S. Chuprin, A. A. Pavlov, A. V. Vologzhanina, E. G. Lebed, Y. V. Zubavichus and Y. Z. Voloshin, Inorg. Chim. Acta, 2017, 463, 29-35.

40 G. Cecot, M. Marmier, S. Geremia, R. D. Zorzi, A. V. Vologzhanina, P. Pattison, E. Solari, F. F. Tirani, R. Scopelliti and K. Severin, J. Am. Chem. Soc., 2017, 39, 8371-8381.

41 G. Cecot, B. Alameddine, S. Prior, R. D. Zorzi, S. Geremia, R. Scopelliti, F. T. Fadaei, E. Solari and K. Severin, Chem. Commun., 2016, 52, 11243-11246.

42 J. L. Bila, J. Pijeat, A. Ramorini, F. Fadaei-Tirani, R. Scopelliti, E. Baudat and K. Severin, Dalton Trans., 2019, 48, 4582-4588. 43 N. Baig, S. Shetty, S. Al-Mousawi, F. Al-Sagheer and B. Alameddine, Polymer, 2018, 151, 164-170.

44 B. Alameddine, S. Shetty, N. Baig, S. Al-Mousawi and F. AlSagheer, Polymer, 2017, 122, 200-207.

45 Z. Zhu and T. M. Swager, Org. Lett., 2001, 3, 3471-3474.

46 M. Morel, C. Aguilera, V. Jiménez, L. Basáez, P. Gebhardt and

S. Heggie, Liq. Cryst., 2012, 39, 847-856.

47 B. Alameddine, N. Baig, S. Shetty, S. Al-Mousawi and F. AlSagheer, J. Polym. Sci., Part A: Polym. Chem., 2018, 56, 931937.

48 J. C. Sanchez and W. C. Trogler, J. Mater. Chem., 2008, 18, 3143-3156.

49 S. Shetty, N. Baig, S. Al-Mousawi, F. Al-Sagheer and B. Alameddine, Polymer, 2019, 178, 121606.

50 S. Peng, S. Yan, N. Wang, W. Nan, J. Wang, X. Chen, C. Wang, X. Qi and S. Dai, RSC Adv., 2018, 8, 12701-12707.

51 A. Velamakanni, K. J. Ganesh, Y. Zhu, P. J. Ferreira and R. S. Ruoff, Adv. Funct. Mater., 2009, 19, 3926-3933.

52 Y.-C. Lin, J. Hong, C.-N. Yen, S.-Y. Tong, M.-J. Tung, H.-W. Shiu, C.-H. Chen and M.-T. Lin, Jpn. J. Appl. Phys., 2015, 54, 033002.

53 N. Baig, S. Shetty, S. Al-Mousawi and B. Alameddine, Polym. Chem., 2020, 11, 3066-3074.

54 Y. H. Abdelmoaty, T.-D. Tessema, F. A. Choudhury, O. M. ElKadri and H. M. El-Kaderi, ACS Appl. Mater. Interfaces, 2018, 10, 16049-16058.

55 M. Ansari, A. Alam, R. Bera, A. Hassan, S. Goswami and N. Das, J. Environ. Chem. Eng., 2020, 8, 103558.

56 H. Guan, D. Zou, H. Yu, M. Liu, Z. Liu, W. Sun, F. Xu and Y. Li, Frontiers in Materials, 2019, 6, 12.

57 D. Shetty, T. Skorjanc, J. Raya, S. K. Sharma, I. Jahovic, K. Polychronopoulou, Z. Asfari, D. S. Han, S. Dewage, J.-C. Olsen, R. Jagannathan, S. Kirmizialtin and A. Trabolsi, ACS Appl. Mater. Interfaces, 2018, 10, 17359-17365. 
58 D. Chen, Y. Fu, W. Yu, G. Yu and C. Pan, Chem. Eng. J., 2018, 334, 900-906.

59 M. Liu, C. Yao, C. Liu and Y. Xu, Sci. Rep., 2018, 8, 14071.

60 T. Geng, W. Zhang, Z. Zhu, G. Chen, L. Ma, S. Ye and Q. Niu, Polym. Chem., 2018, 9, 777-784.

61 G. Li, C. Yao, J. Wang and Y. Xu, Sci. Rep., 2017, 7, 13972.

62 X. Qian, Z.-Q. Zhu, H.-X. Sun, F. Ren, P. Mu, W. Liang, L. Chen and A. Li, ACS Appl. Mater. Interfaces, 2016, 8, 21063-21069.

63 K. C. Park, J. Cho and C. Y. Lee, RSC Adv., 2016, 6, 7547875481.

64 R. M. Weiss, A. L. Short and T. Y. Meyer, ACS Macro Lett., 2015, 4, 1039-1043.
65 L. Wang, P. Chen, X. Dong, W. Zhang, S. Zhao, S. Xiao and Y. Ouyang, RSC Adv., 2020, 10, 44679-44687.

66 M. Shahnawaz Khan, M. Khalid and M. Shahid, Adv. Mater., 2020, 1, 1575-1601.

67 M. Saghian, S. Dehghanpour and M. Sharbatdaran, RSC Adv., 2020, 10, 9369-9377.

68 A. Ahmad, S. Mohd-Setapar, S. C. Chuo, A. Khatoon, W. Wani, R. Kumar and M. Rafatullah, RSC Adv., 2015, 5, 30801-30818.

69 N. Baig, S. Shetty, S. Al-Mousawi and B. Alameddine, Polym. Chem., 2021, DOI: 10.1039/D1PY00193K. 